\title{
AIR POLLUTION AND EMERGENCY DEPARTMENT VISITS FOR CONJUNCTIVITIS: A CASE-CROSSOVER STUDY
}

\section{MIECZYSŁAW SZYSZKOWICZ ${ }^{1}$, TERMEH KOUSHA ${ }^{2}$, and JESSICA CASTNER ${ }^{3}$}

\author{
${ }^{1}$ Health Canada, Ottawa, Canada \\ Population Studies Division \\ ${ }^{2}$ University of Ottawa, Ottawa, Canada \\ Department of Mathematics and Statistics \\ ${ }^{3}$ University at Buffalo, Buffalo, United States of America \\ School of Nursing
}

\begin{abstract}
Objectives: The purpose of this study was to examine the associations between emergency department (ED) visits for conjunctivitis and ambient air pollution levels in urban regions across the province of Ontario, Canada. Material and Methods: Information from the National Ambulatory Care Reporting System was used to create time-series records, for the period of April 2004 to December 2011, on emergency department visits of patients suffering from conjunctivitis. A total of 77439 emergency department visits for conjunctivitis were analyzed. A time-stratified case-crossover design was applied, completed with meta-analysis in order to pool inter-city results. Odds ratio (OR) for an emergency department visit was calculated in different population strata per one-unit increase (one interquartile range - IQR increase in a pollutant's daily level) while controlling for the impacts of temperature and relative humidity. Results: Statistically significant positive results were observed in the female population sample, for nitrogen dioxide $\left(\mathrm{NO}_{2}\right)$ exposure lagged 5-8 days, with the highest result for the 7-day lag $(\mathrm{OR}=1.035,95 \% \mathrm{CI}: 1.018-1.052)$ and for fine particulate matter with a median aerodynamic diameter of less than $2.5 \mu \mathrm{m}\left(\mathrm{PM}_{2.5}\right)$, for lags 6 and 7 days, with the highest result for lag $7(\mathrm{OR}=1.017$, 95\% CI: 1.003-1.031). In the male population sample, statistically significant positive results were observed for $\mathrm{NO}_{2}$ at lag 5 days $(\mathrm{OR}=1.024,95 \% \mathrm{CI}$ : $1.004-1.045)$ and for ozone $\left(\mathrm{O}_{3}\right)$, at lags $0-3$ and 7 days, with the highest result for lag 0 $(\mathrm{OR}=1.038,95 \% \mathrm{CI}: 1.012-1.056)$. Also for males, statistically significant results were observed in the case of $\mathrm{PM}_{2.5}$ exposure lagged by 5 days $(\mathrm{OR}=1.003,95 \% \mathrm{CI}: 1.000-1.038)$ and sulfur dioxide $\left(\mathrm{SO}_{2}\right)$ exposure lagged by 1 and 2 days $(\mathrm{OR}=1.016,95 \% \mathrm{CI}: 1.000-1.031$ and $\mathrm{OR}=1.018,95 \% \mathrm{CI}: 1.002-1.033)$. Conclusions: The findings of this study suggest that there are associations between levels of air pollution and ED visits for conjunctivitis, with different temporal trends and strength of association by age, sex, and season.
\end{abstract}

Key words:

Air pollution, Case-crossover, Emergency department visit, Exposure, Conjunctivitis, Multi-city study

Received: August 25, 2014. Accepted: May 29, 2015.

Corresponding author: M. Szyszkowicz, Health Canada, Population Studies Division, 200 Eglantine Driveway, Ottawa, K1A 0K9, Canada (e-mail: mietek.szyszkowicz@canada.ca). 


\section{INTRODUCTION}

Vehicles, factories, and power plants are among the major sources producing the daily air pollution that affects human health. Numerous studies have confirmed that the ambient air pollution is a risk factor for respiratory conditions, such as asthma [1-12]. Studies also have linked ambient air pollution to non-respiratory conditions, such as cardiovascular disease [12,13], appendicitis [14], headaches and migraines [15], skin conditions [16-20], eye discomfort and conjunctivitis [17,21-23]. While air pollution is linked to eye discomforts, conjunctivitis in particular, in several studies of cellular microbiology and tissue pathology, and in individual-level reports [24-36], the population burden of these disorders is not well characterized. The majority of the direct costs, as well as the treatment of conjunctivitis, are managed by patients and families through self-care with use of the over-the-counter products [37,38].

In this paper, correlations between exposure to ambient air pollution and emergency department (ED) visits for conjunctivitis are investigated. Acute ocular exposures to high concentrations of air pollutants are well known to cause pain, redness, burning, and watering of the eyes [39]. An estimated $15-40 \%$ of the population in developed countries are affected by conjunctivitis [40,41]. Inflammatory eye disorders are increasingly linked to cost, quality of life, unnecessary antibiotic use, and lost school/ work productivity [37,42-45]. In addition, conjunctivitis is among the most common reasons for emergency department (ED) visits, particularly for children [46,47].

The conjunctiva is the eye's protective barrier to the environment, comprised of membranes that enfold the external portion of the sclera (white portion of the eye) and the inner eyelid [40]. The laymen's term for conjunctivitis is "pink eye," due to the pink or red appearance from inflamed and edematous blood vessels and tissues when infected, irritated, or injured. Conjunctivitis, which is often categorized as either allergic or infectious, encompasses a cluster of clinically nonspecific signs and symptoms that include blurred vision, sensitivity to light, pain, foreign body sensations, itching, burning, discharges, and inability to tolerate contact lenses [40]. The conjunctiva is continuously bathed in a tear film, which acts as both a lubricant for eye movement and a protective barrier to dilute and remove harmful environmental impurities.

Higher levels of ambient air pollution have been correlated with adverse effects on the tear film, ocular mucosa, ocular surface, and eyelid margins [30,36,39,48-50]. Several population studies have examined the associations between air pollution levels and ED visits for eye diseases $[17,21,23,24]$. To our knowledge, no multi-city studies have investigated this link for cities in North America. Filling this gap in the epidemiologic literature is important; multi-city studies are known to give more reliable results, less liable to biases in comparison to studies concerned with individual urban centers [51].

There is strong motivation for setting multi-city studies in Ontario, Canada. Most of the population of Ontario inhabits the territory along a heavily trafficked and industrialized international border with the United States. Polluting activities and population health in the border regions in both countries are intricately linked, as the gaseous pollutants are known to travel long distances [23] and cause cross-border impacts.

The results reported in this paper were obtained using a case-crossover (CC) technique augmented by meta-analysis. The CC routine investigates correlations between intermittent events (exposure to ambient air pollution) and public health outcomes (variations in the frequency of ED visits for conjunctivitis). The investigation embraced nine cities across Ontario, Canada. One of the goals of the study was to confirm findings of past per-city investigations dealing with air pollution and conjunctivitis [17].

We tested the hypothesis that higher levels of ambient air pollution increased the risk of ED visits for conjunctivitis. The test consists of correlating the daily number of ED visits for conjunctivitis (International Classification 
of Diseases (tenth revision) - ICD-10 codes H10), which stands for the outcome variable, with the daily levels of ambient air pollutants - nitrogen dioxide, ozone, fine particulate matter - which represent the exposure variables. In similar research, weather variables are routinely controlled for as confounding; we controlled the contributions of the most important confounders of the health outcomes: temperature and humidity.

\section{MATERIAL AND METHODS}

\section{Health data}

The data pertaining to ED visits were retrieved from the National Ambulatory Care Reporting System (NACRS). The NACRS contains information collected at the time of healthcare service from participating hospitals, and includes information on day and night surgeries, on services provided in outpatient clinics, and the ED data for all hospital and community-based ambulatory care [52]. The cases of conjunctivitis in the ED reporting are distinctly coded (with symbol H10 (ICD-10)); that enabled creating the daily counts of the visits. Data were assembled from hospitals in 9 cities in Ontario, Canada: Algoma, Halton, Hamilton, London, Ottawa, Peel, Toronto, Windsor, and York. The study time period is April 2004 December 2011, almost 7 years.

\section{Environmental data}

Air pollution data were obtained from Environment Canada's National Air Pollution Surveillance Program (NAPS) [53]. The locally observed daily level of a pollutant was defined as the daily average of its hourly readings at a NAPS station. A patient's daily exposure to a pollutant was defined by the average of the pollutant's daily levels at the NAPS stations situated within $35-\mathrm{km}$ perimeter from the patient's residence (identified by patient's postal code). The ambient pollution's measurements were completed for ozone $\left(\mathrm{O}_{3}\right)$, nitrogen dioxide $\left(\mathrm{NO}_{2}\right)$, fine particulate matter $(\mathrm{PM})$ with a median aerodynamic diameter of less than $2.5 \mu \mathrm{m}\left(\mathrm{PM}_{2.5}\right)$, and sulfur dioxide $\left(\mathrm{SO}_{2}\right)$.

Weather variables included temperature (in degree Celsius) and relative humidity (in percentage points). The daily values of weather parameters were calculated by averaging the hourly data and next averaging across the Environment Canada stations situated within $100 \mathrm{~km}$ distance from patient's postal code.

\section{Statistics}

This study was executed in 2 stages of analysis. In the 1st stage, the case-crossover (CC) design was applied [54]. The CC design, introduced to epidemiology in 1991, and now commonly used in the air pollution studies, has the advantage of neutralizing the confounders of health outcomes as the individual's health characteristics and of reducing the effects of slowly varying covariates (e.g., seasonal effects) [54-56]. The CC method has aspects of the case control analysis: it applies controls. A patient's exposure on the day of his/her visit to ED is compared to the patient's exposure on pre-defined other days, when it is anticipated he/she was not seeking professional help at ED. In this study, the control days were selected in the month of patient's visit to the ED and they matched the day-of-week parameter of the visit (thus, each case was presented with 3 or 4 controls).

The p-values less than 0.05 were considered statistically significant. The results of $\mathrm{CC}$ analysis were reported as odds ratios (OR) and their $95 \%$ confidence intervals (CI). The odds ratios were calculated separately for each pollutant in each city, using the Cox proportional hazard regression (PROC PHREG) procedure in SAS Visual Analytics (Enterprise Guide, version 4.2). The modeling was performed feeding into the models the pollution variables and meteorological factors lagged by the same number of days, from 0 to 8 days.

At the 2nd stage of analysis, the per-city estimates were combined, by performing meta-analysis of the estimates 
and their standard errors, in order to characterize the overall effect relevant to all cities. Applying fixed-effects modeling (assuming that the individual estimates reflect action of the same underlying factor), the pooled estimators and their standard errors were calculated. The computational tasks were executed using the R language facility [57].

It is to be noted that fixed-effect analysis allows for a more precise estimate of the associations between exposure and public health outcomes - by pooling the results across multiple studies [58].

\section{RESULTS}

Figure 1 shows the numbers (counts) of ED visits for conjunctivitis ( $\mathrm{N}=77439)$ stratified by sex and by age from 0 to 98 years. The patients 98 years old and older are included in the 98-year category. In Table 1, there appears the season category; this category is defined as cold weather months (October-March) or warm weather months (April-September). The table shows the number of the ED visits - stratified by sex, season, city, and ICD-10 code - that occurred in the period of

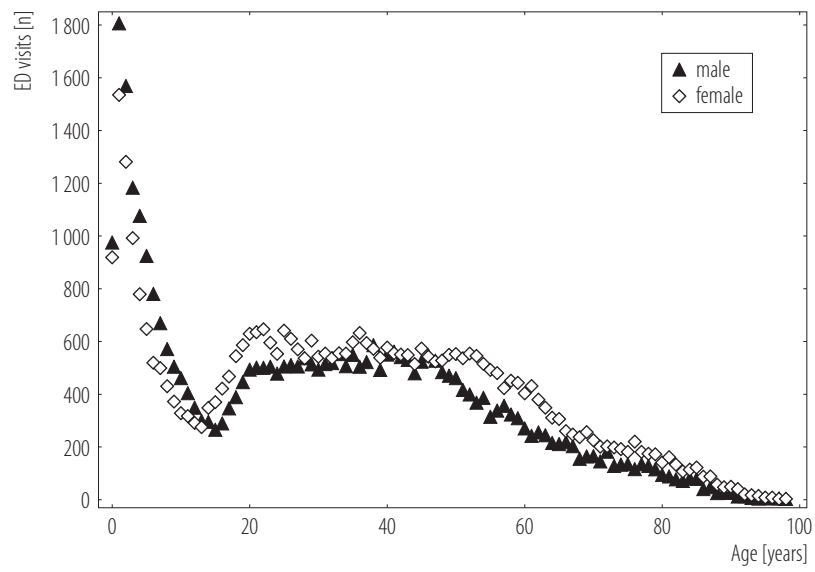

Fig. 1. Frequency, differentiated by sex, of emergency department (ED) visits for conjunctivitis vs. age of respondents

April 2004 - December 2011. It can be seen that majority of the visits have assigned diagnostic "unspecified conjunctivitis" (ICD-10 code H10.9). The number of visits is higher in the warm season $(58 \%)$ than in the cold season and higher for females $(52 \%)$ than for males. Table 2 shows the characteristics of relative humidity and temperature of all involved cities. Table 3 shows the descriptive air pollution statistics, by city.

Table 1. Emergency department visits by sex, season, city and type of conjunctivitis

\begin{tabular}{|c|c|}
\hline Variable & $\begin{array}{l}\text { Emergency department visits } \\
(\mathrm{N}=77439) \\
{[\mathrm{n}(\%)]}\end{array}$ \\
\hline \multicolumn{2}{|l|}{ Sex } \\
\hline female & $40408(52)$ \\
\hline male & $37031(48)$ \\
\hline \multicolumn{2}{|l|}{ Season } \\
\hline cold (October-March) & $32765(42)$ \\
\hline warm (April-September) & $44674(58)$ \\
\hline \multicolumn{2}{|l|}{ City/Region } \\
\hline Algoma & $8755(11)$ \\
\hline Halton & $4726(6)$ \\
\hline Hamilton & $10050(13)$ \\
\hline London & $6173(8)$ \\
\hline
\end{tabular}


Table 1. Emergency department visits by sex, season, city and type of conjunctivitis - cont.

\begin{tabular}{|c|c|}
\hline Variable & $\begin{array}{l}\text { Emergency department visits } \\
(\mathrm{N}=77439) \\
{[\mathrm{n}(\%)]}\end{array}$ \\
\hline \multicolumn{2}{|l|}{ City/Region - cont. } \\
\hline Ottawa & $8129(10)$ \\
\hline Peel & $8166(11)$ \\
\hline Toronto & $21566(28)$ \\
\hline Windsor & $3264(4)$ \\
\hline York & $6610(9)$ \\
\hline \multicolumn{2}{|l|}{ Type of conjunctivitis (ICD-10 code) } \\
\hline mucopurulent (H10.0) & $2018(3)$ \\
\hline acute atopic (H10.1) & $7281(9)$ \\
\hline other acute (H10.2) & $724(1)$ \\
\hline acute, unspecified (H10.3) & $4463(6)$ \\
\hline chronic (H10.4) & $61(<1)$ \\
\hline blepharoconjuntivitis (H10.5) & $401(1)$ \\
\hline other (H10.8) & $6867(9)$ \\
\hline unspecified (H10.9) & $55624(72)$ \\
\hline
\end{tabular}

ICD-10 - International Classification of Diseases (tenth revision).

Table 2. Characteristics of relative humidity and temperature by cities

\begin{tabular}{|c|c|c|c|c|c|c|}
\hline \multirow[t]{2}{*}{ City } & \multicolumn{3}{|c|}{$\begin{array}{c}\text { Relative humidity } \\
{[\%]}\end{array}$} & \multicolumn{3}{|c|}{$\begin{array}{c}\text { Temperature } \\
{\left[{ }^{\circ} \mathrm{C}\right]} \\
\end{array}$} \\
\hline & $\min .-\max$ & $\mathrm{M}$ & IQR & $\min .-\max$ & M & IQR \\
\hline Algoma & $29.0-100.0$ & 75.1 & 14.7 & $-26.2-26.4$ & 6.2 & 16.4 \\
\hline Halton & $35.7-95.5$ & 70.5 & 15.9 & $-17.9-31.0$ & 9.7 & 16.1 \\
\hline Hamilton & $36.2-100.0$ & 76.2 & 15.7 & $-19.8-30.0$ & 9.0 & 16.8 \\
\hline London & $33.2-98.9$ & 73.5 & 14.5 & $-19.7-30.6$ & 9.1 & 16.9 \\
\hline Ottawa & $26.7-100.0$ & 72.2 & 18.4 & $-26.6-29.6$ & 7.9 & 17.7 \\
\hline Peel & 27.6-99.8 & 70.2 & 16.1 & $-20.3-31.7$ & 9.7 & 16.9 \\
\hline Toronto & 24.6-99.7 & 72.5 & 16.8 & $-19.3-31.5$ & 10.1 & 16.2 \\
\hline Windsor & $32.4-97.4$ & 69.5 & 16.3 & $-19.5-30.4$ & 11.0 & 17.3 \\
\hline York & $30.1-100.0$ & 70.1 & 16.5 & $-20.0-32.0$ & 9.1 & 16.9 \\
\hline
\end{tabular}

min. - minimal value; $\max$ - maximal value; $\mathrm{M}$ - mean; IQR - interquartile range. 
Table 3. Descriptive air pollution statistics by cities

\begin{tabular}{|c|c|c|c|c|c|c|c|c|c|c|c|c|}
\hline \multirow{2}{*}{ City/Region } & \multicolumn{3}{|c|}{$\begin{array}{l}\mathrm{NO}_{2} \\
{[\mathrm{ppb}]}\end{array}$} & \multicolumn{3}{|c|}{$\begin{array}{c}\mathrm{O}_{3} \\
{[\mathrm{ppb}]}\end{array}$} & \multicolumn{3}{|c|}{$\begin{array}{c}\mathrm{PM}_{2.5} \\
{\left[\mathrm{mg}_{2.5} \mathrm{~m}^{-3}\right]}\end{array}$} & \multicolumn{3}{|c|}{$\begin{array}{l}\mathrm{SO}_{2} \\
{[\mathrm{ppb}]}\end{array}$} \\
\hline & $\min .-\max$ & M & IQR & $\min .-\max$ & M & IQR & $\min .-\max$ & $\mathrm{M}$ & IQR & $\min .-\max$ & $\mathrm{M}$ & IQR \\
\hline Algoma & $0.0-24.0$ & 5.1 & 4.0 & $2.0-80.0$ & 28.5 & 14.0 & $0.0-29.0$ & 5.3 & 4.3 & $0.0-17.0$ & 1.1 & 2.0 \\
\hline Halton & $1.0-51.2$ & 12.9 & 7.7 & $2.0-67.7$ & 25.8 & 14.0 & $0.5-34.2$ & 7.7 & 5.8 & $0.0-14.0$ & 2.3 & 2.0 \\
\hline Hamilton & $1.7-63.0$ & 13.9 & 9.5 & $1.5-70.0$ & 26.3 & 13.5 & $0.0-64.2$ & 9.8 & 7.6 & $0.0-35.5$ & 4.1 & 4.1 \\
\hline London & $0.0-51.0$ & 10.9 & 7.0 & $1.0-66.0$ & 26.3 & 14.0 & $0.0-66.3$ & 9.5 & 7.2 & $0.0-15.0$ & 1.7 & 1.0 \\
\hline Ottawa & $1.0-47.0$ & 8.7 & 7.0 & $1.0-66.5$ & 24.1 & 13.0 & $0.0-67.7$ & 7.0 & 6.3 & $0.0-13.0$ & 0.8 & 1.0 \\
\hline Peel & $2.0-54.0$ & 13.2 & 9.5 & $1.0-69.5$ & 25.0 & 13.5 & $0.0-64.9$ & 8.5 & 6.8 & $0.0-12.0$ & 1.4 & 1.5 \\
\hline Toronto & $4.5-62.1$ & 18.5 & 9.4 & $1.5-60.7$ & 22.5 & 13.4 & $0.0-66.8$ & 9.3 & 7.4 & $0.0-13.7$ & 1.8 & 1.8 \\
\hline Windsor & $2.4-55.5$ & 15.6 & 8.1 & $1.0-68.5$ & 25.7 & 16.1 & $0.8-33.6$ & 9.5 & 7.4 & $0.0-24.3$ & 4.3 & 4.5 \\
\hline York & $0.0-47.0$ & 8.2 & 7.0 & $3.0-71.0$ & 29.2 & 14.0 & $0.0-27.0$ & 6.7 & 6.0 & $0.0-8.0$ & 1.2 & 2.0 \\
\hline
\end{tabular}

$\mathrm{NO}_{2}$ - nitrogen dioxide; $\mathrm{O}_{3}$ - ozone; $\mathrm{SO}_{2}$ - sulfur dioxide; $\mathrm{PM}_{2.5}$ - particulate matter with a median aerodynamic diameter of less than $2.5 \mu \mathrm{m}$. Other abbreviations as in Table 2.

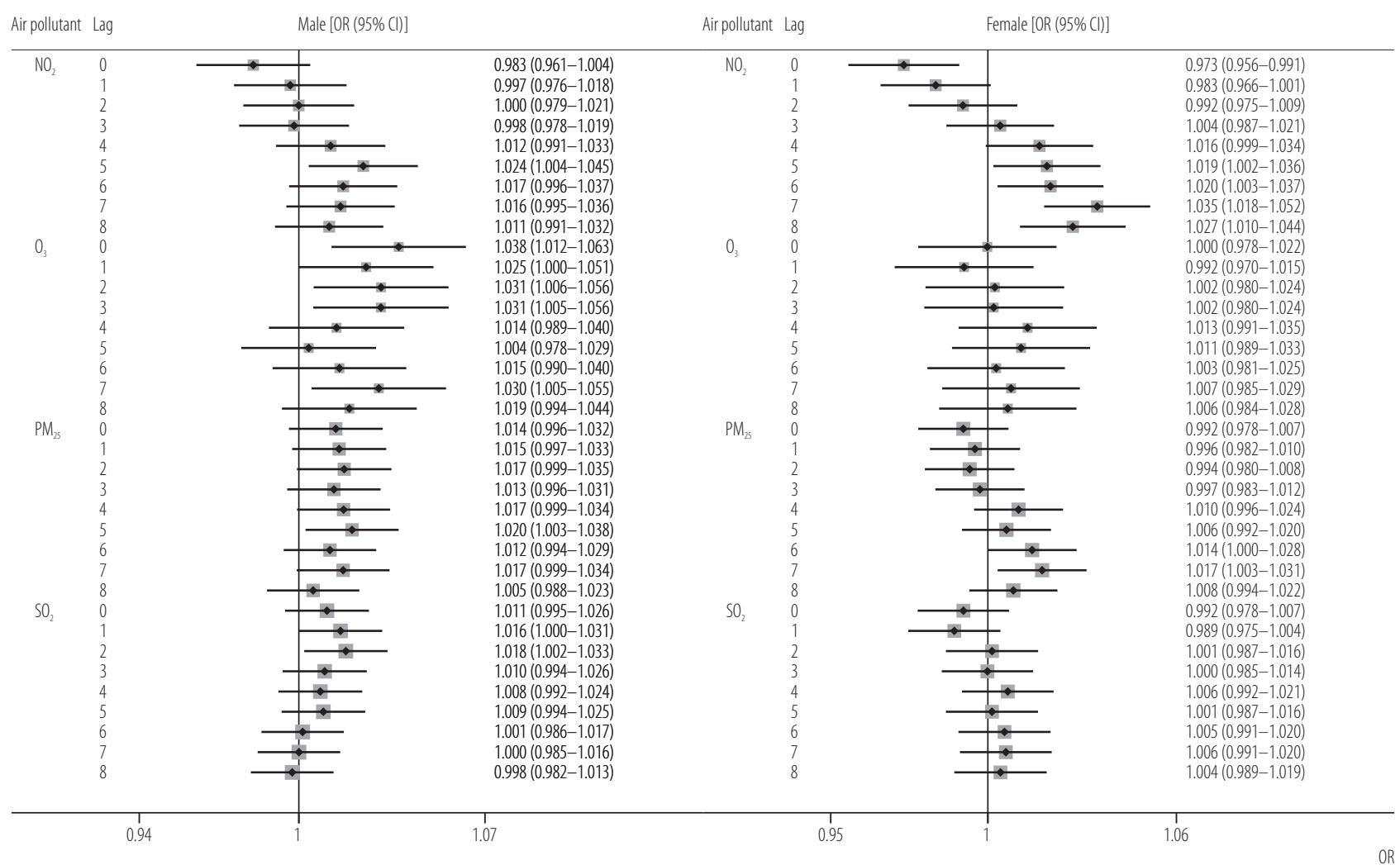

OR - odds ratio; CI - confidence intervals. Other abbreviations as in Table 3.

Fig. 2. All-season fixed-effect exposure and emergency department (ED) visit estimates - pooling among 9 cities in Ontario 


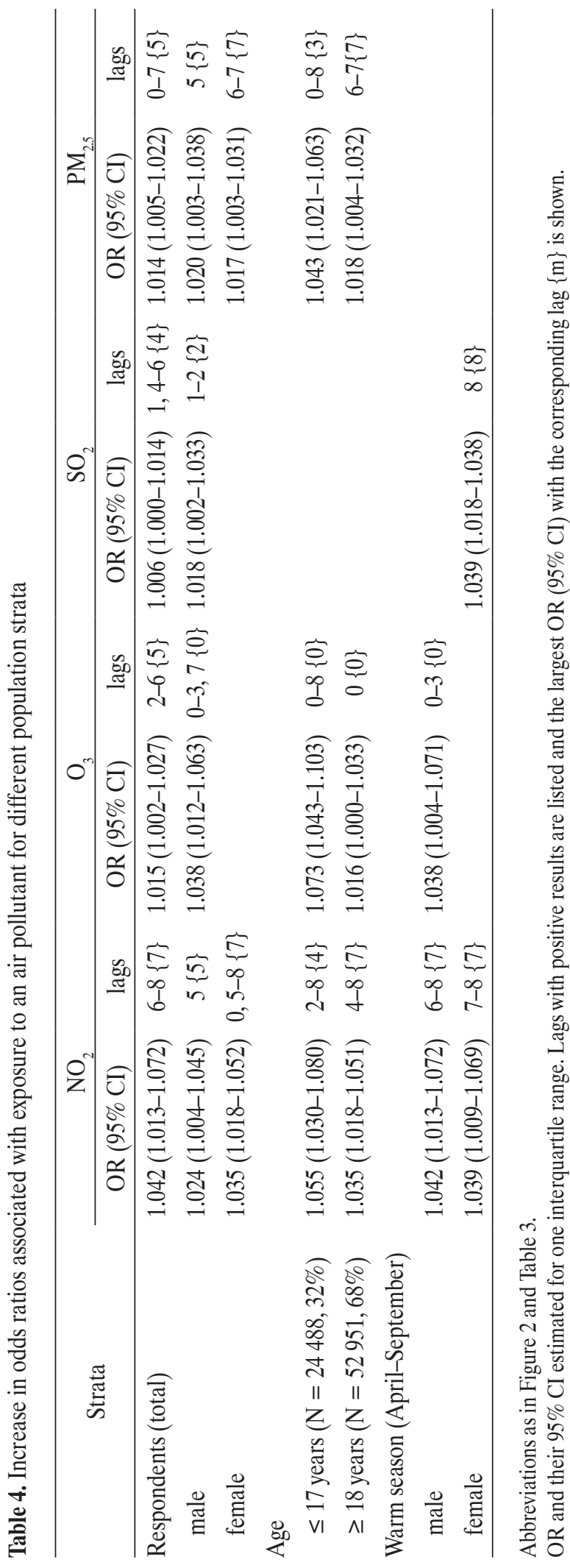

The results of pooling the fixed-effect estimates (timeindependent population-average pollution effects on conjunctivitis) throughout the 9 cities are presented in Figure 2, separately for males (left panel) and females (right panel). The ORs and their $95 \% \mathrm{CI}$ were calculated taking the interquartile range (IQR $=75-25$ th percentiles) for the unit increase in a pollutant's level. Table 4 gives a summary of the positive results: the delays between increases in exposure and the most significant increases in the numbers of ED visits (per unitary increase in the exposure); the risks are estimated in diverse population strata.

\section{DISCUSSION}

Investigation of the impact of exposure to ambient air pollution on the frequency of ED visits for conjunctivitis reveals many significant associations between recent (during the preceding week) exposure events and variations in the frequency of the visits. Similar multi-city studies have been conducted in Taiwan, where the air pollution concentrations are much higher [21]. Single-site studies have been completed in Edmonton, Alberta, Canada, and in Paris, France [17,23].

This study, besides providing corroborating evidence with previously published studies, adds to the current science in several important ways: this is one of the largest multicity studies in North America concerning air pollution and ED visits for conjunctivitis, it investigates the latency, up to 8 days, in exposure effects, and it stratifies results by gender and age. All 4 pollutants were found responsible for increases in counts of ED visits for conjunctivitis in the male population, while episodes of higher $\mathrm{NO}_{2}$ or $\mathrm{PM}_{2.5}$ were correlated with increases in the ED counts when investigating the conjunctivitis cases in the female population.

There are apparent differences in health outcomes in male vs. female population and in younger vs. older population. The most evident factors differentiating health outcomes in different populations are dissimilar exposures (possibly 
due to unalike ways of active life) and different physiological sensibilities to the pollution factors affecting health (and many possible cofactors, as ultraviolet (UV) radiation, weather events, and allergens).

Different sensibilities may cause distinctly differentiated delays in pollution health effects. For example, the negative significant results detected in the female stratum could be the result of harvest phenomena which may be caused by greater exposure-to-effect latency in the female population, which, in turn, may be a result of specific skin self-care patterns in the female population. Also, exposure - health effect associations are stronger in the group of younger persons (17 or younger, especially in the cases of exposure to $\mathrm{O}_{3}$ and $\mathrm{PM}_{2.5}$, where significant positive results were found for all exposure lags). This suggests that children and young adults are more vulnerable to conjunctivitis infections.

The Edmonton study found statistically significant $\mathrm{O}_{3}$ impacts only in the female population [17]; this study finds the impacts in the male stratum only. The differences between studies in gender-specific outcomes may have different origins: the former study used version 9 of the ICD codes, and included only results of unspecified conjunctivitis, while this study deals with broader range of the conjunctivitis cases: those flagged by diagnosis code "10." Also, the applied statistical methods are different. However, the gender-specific different outcomes may require an additional study.

The Taiwan multi-city study [21], which applies the random-effects approach to the meta-analysis rather than the fixed-effects tactic, corroborates the thesis that high levels of air pollutants $\left(\mathrm{NO}_{2}, \mathrm{SO}_{2}, \mathrm{O}_{3}\right.$ and $\left.\mathrm{PM}_{10}\right)$ increase the chances of an ED visit, in the immediate post-exposure period, for the patients suffering from nonspecific conjunctivitis. However, the study tested the cumulative exposure, accumulated in the period of up to 5 days preceding the ED visit.

The Taiwan study [21] findings about an immediate impact of $\mathrm{O}_{3}$ agree with the corresponding results obtained in our study, however, their method could not find the strongly delayed (7 days) effects in the female population of the $\mathrm{NO}_{2}$ and $\mathrm{PM}_{2.5}$ exposures. By analyzing genders separately, we can see that, in the female population, the odds of $\mathrm{ED}$ visit for conjunctivitis immediately after exposure to $\mathrm{NO}_{2}$ are small and that the odds were increasing with time. This scenario results, arguably, from a developing infection rather than from an accumulating exposure.

The Paris study (30 883 patients) [23] reported that levels of $\mathrm{NO}_{2}$ were correlated with conjunctivitis and ophthalmological ED visits occurring 2 days after exposure. They took into account additional weather parameter, the wind strength, which appears to strongly influence the development of eye infections. Nevertheless, the overall conclusions are well related to the findings of our study.

Conjunctivitis is a common childhood condition $[43,46,47]$ causing frequent ED visits of young patients; in our data, the frequency peaks at age 1 , for both genders. The incidence then steadily decreases until the mid-teen years. From the mid-teens through older adulthood, more females visited the ED for conjunctivitis than males. A 2nd peak, and plateau, is seen in both genders from early adulthood until middle-age, with a subsequent steady decrease in the ED numbers after the age of 47 for males and 54 for females.

It is plausible that both biological and social gender differences cause different trends in the 2 sexes. For example, the age where female visits outnumber male visits coincides with puberty, a trend mirrored in allergy and asthma prevalence $[59,60]$. Further research is needed to clarify how gender-related biological mechanisms or gendered social norms condition human organism's responses to the ambient pollutants. Personal aspects as hygienic habits [61], wearing of eye cosmetics, caretaking roles - increased exposure to infections from children - and time spent outdoors vs. staying home, are considered important factors in conjunctivitis morbidity.

The striking difference between genders: quite delayed (7 days) effect of exposure to $\mathrm{NO}_{2}$ in the female 
population vs. immediate reaction to the exposure among males, may be explained by the feminine tendency to treat most of eye irritations at home with over-the-counter and self-care methods [37,38]. It is plausible that the low level of irritation, if any, on the day of exposure is most amenable to self-care interventions, while sub-clinically increasing the risk for later infection or allergic irritation [44]. It is noteworthy that when taking into account both genders, the strongest effects of an exposure to nitrogen dioxide occurred 5-7 days after exposure; this timeframe coincides with the typical incubation period for viral (5-12 days) and bacterial (1-7 days) conjunctivitis [40].

There is progressing understanding of the mechanisms by which air pollution impacts eye health. Several advancing, mechanistic theories are supported by preliminary empirical data from a number of studies [25-36,40]. Allergic inflammation of the respiratory tract (evidenced by allergic asthma attacks) and eyes are highly correlated with air pollution levels $[62,63]$. The pollution increases oxidative stress, thus impeding the antioxidant defenses of the eye and inducing a cycle of inflammation and irritation, which strengthens allergen response, leading to clinical allergic conjunctivitis [64]. Higher levels of ambient air pollution may increase the sensitivity to other common allergens $[65,66]$. In addition, particulate matter may transport infectious agents from the environment directly into the eye [67]. Temporal associations between air pollutants and disruptions in homeostasis of the eye's tear film, ocular mucosa, ocular surface, and eyelid margins were reported in many publications [30,36,39,48-50,68-70]. Arguably, patients with chronic tear film instability are more susceptible to bacterial infections; it is unclear if the acute impact from air pollution also increases this risk [71,72]. Further studies are required to better understand the linkages between conjunctivitis and air pollution, and to determine the long term effects of air pollutants on the eye, which are largely unknown [23]. Because of the substantial underlying social costs associated with the occurrences of conjunctivitis [37,38], a cost-benefit analysis may be of the essence in future studies.

The findings from this study must be interpreted in light of the limitations that are commonplace in the population based investigations of the air pollution that intensify health services utilization. First, there is a risk of an ecological fallacy in pollutant exposure data: the centralized air monitor data represent the average population exposure to pollution, and not personal exposure. Thus, individual variability in exposure introduces measurement error. However, this common exposure misclassification has been shown to underestimate the risk, so our results are likely conservative estimates of the true effect [73]. Currently, the cost and availability of personal exposure monitoring for multi-city studies does not present a feasible alternative. In addition, each lag ( $0-8$ for each pollutant) requires a separate statistical test on the same data, increasing the risk for spurious results (type I error). Still, pooling data using the meta-analysis and meta-regression technique serves to limit this potential statistical error [58]. Finally, this study demonstrates correlation, not causation, between air pollutants and ED visit for conjunctivitis. It is likely that our study underestimated the effect of air pollution on conjunctivitis. In the studies in Edmonton, Taiwan, and Paris much stronger exposure impacts have been seen. The higher results are arguably the large-city effect; the multi-city fixed effects are less visible among smaller, widely distributed towns. Also social differences, as self-care habits vs. accessibility of professional help, may play important role. Since most interventions for conjunctivitis involve self-care and products purchased over-the-counter [37,38], the relationships reported in this study can be expected to represent more extreme cases of conjunctivitis which cause ED utilization. Also, individuals are exposed to a multi-pollutant environment, with many compounds that are not measured by current air monitoring stations; the individual pollutants measured in this study may also serve as a proxy for unmeasured pollutants, or a multi-pollutant mixture. 


\section{CONCLUSIONS}

Conjunctivitis is a common population health burden with costs that include reduced quality of life, unnecessary antibiotic use, and lost school/work productivity impacts. This study supports the thesis that there is an association between ambient air pollution and the incidence of conjunctivitis across Ontario, Canada. Impacts of an exposure and the timing of health effects vary between sexes and ages. High-precision study is needed to determine the most important biological and social modifiers of the exposure-tohealth effects path, wherein the pathogenesis, prevalence, and severity of allergic and infectious conjunctivitis are researched.

\section{REFERENCES}

1. Valacchi G, Fortino V, Bocci V. The dual action of ozone on the skin. Br J Dermatol. 2005;153:1096-100, http://dx.doi. org/10.1111/j.1365-2133.2005.06939.x.

2. Fridovich I. The biology of oxygen radicals. Science. 1978;201:875-80, http://dx.doi.org/10.1126/science.210504.

3. Aris RM, Christian D, Hearne PQ, Kerr K, Finkbeiner WE, Balmes JR. Ozone-induced airway inflammation in human subjects as determined by airway lavage and biopsy. Am Rev Respir Dis. 1993;148:1363-72, http://dx.doi.org/10.1164/ajrc$\mathrm{cm} / 148.5 .1363$.

4. Pryor WA. Ozone in all its reactive splendor. J Lab Clin Med. 1993;122:483-6.

5. Camhi SL, Lee P, Choi AM. The oxidative stress response. New Horiz. 1995;3:170-82.

6. Devlin RB, Raub JA, Folinsbee LJ. Health effects of ozone. Sci Med. 1997;May/Jun:8-17.

7. Devlin RB, McDonnell WF, Mann R, Becker S, House DE, Schreinemachers D, et al. Exposure of humans to ambient levels of ozone for 6.6 hours causes cellular and biochemical changes in the lung. Am J Respir Cell Mol Biol. 1991;4:72-81, http://dx.doi.org/10.1165/ajrcmb/4.1.72.

8. Devlin RB, McKinnon KR, Noah T, Becker S, Koren HS. Ozone-induced release of cytokines and fibronectin by alveolar macrophages and airway epithelial cells. Am J Physiol. 1994;266:L612-9.

9. Morrison D, Rahman I, Macnee W. Permeability, inflammation and oxidant status in airspace epithelium exposed to ozone. Respir Med. 2006;100:2227-34, http:/dx.doi. org/10.1016/j.rmed.2005.10.005.

10. Burnett RT, Smith-Doiron M, Stieb D, Raizenne ME, Brook JR, Dales RE, et al. Association between ozone and hospitalization for acute respiratory diseases in children less than 2 years of age. Am J Epidemiol. 2001;153:444-52, http://dx.doi.org/10.1093/aje/153.5.444.

11. Villeneuve PJ, Chen L, Rowe BH, Coates F. Outdoor air pollution and emergency department visits for asthma among children and adults: A case-crossover study in northern Alberta, Canada. Environ Health. 2007;6:40, http://dx.doi. org/10.1186/1476-069X-6-40.

12. Stieb DM, Szyszkowicz M, Rowe BH, Leech JA. Air pollution and emergency department visits for cardiac and respiratory conditions: A multi-city time-series analysis. Environ Health. 2009;8:25, http://dx.doi.org/10.1186/1476-069X-8-25.

13. Wong TW, Lau TS, Yu TS, Neller A, Wong SL, Tam W, et al. Air pollution and hospital admissions for respiratory and cardiovascular diseases in Hong Kong. Occup Environ Med. 1999;56:679-83, http://dx.doi.org/10.1136/oem.56.10.679.

14. Kaplan GG, Dixon E, Panaccione R, Fong A, Chen L, Szyszkowicz M, et al. Effect of ambient air pollution on the incidence of appendicitis. CMAJ. 2009;181:591-7, http://dx.doi. org/10.1503/cmaj.082068.

15. Szyszkowicz M, Kaplan GG, Grafstein E, Rowe BH. Emergency department visits for migraine and headache: A multi-city study. Int J Occup Med Environ Health. 2009; 22:235-42, http://dx.doi.org/10.2478/v10001-009-0024-5.

16. Larrieu S, Lefranc A, Gault G, Chatignoux E, Couvy F, Jouves B. Are the short-term effects of air pollution restricted to cardiorespiratory diseases? Am J Epidemiol. 2009;169:1201-8, http://dx.doi.org/10.1093/aje/kwp032.

17. Szyszkowicz M, Porada E, Searles G, Rowe BH. Ambient ozone and emergency department visits for skin 
conditions. Air Qual Atmos Health. 2012;5:303-9, http:// dx.doi.org/10.1007/s11869-010-0092-5.

18. Xu F, Yan S, Wu M, Li F, Xu X, Song W, et al. Ambient ozone pollution as a risk factor for skin disorders. Br J Dermatol.2011;165:224-5, http://dx.doi.org/10.1111/j.1365-2133. 2011.10349.x.

19. Szyszkowicz M, Porada E, Kaplan GG, Rowe BH. Ambient ozone and emergency department visits for cellulitis. Int J Environ Res Public Health. 2010;7(11):4078-88, http:// dx.doi.org/10.3390/ijerph7114078.

20. Szyszkowicz M, Porada E, Grafstein E, Rowe BH. Ambient ozone as a risk factor for ED visits for cellulitis. Environ Pollut. 2012;1(2):105-11, http://dx.doi.org/10.5539/ep.v1n2p105.

21. Chang CJ, Yang HH, Chang CA, Tsai HY. Relationship between air pollution and outpatient visits for nonspecific conjunctivitis. Invest Ophthalmol Vis Sci. 2012;53:429-33, http://dx.doi.org/10.1167/iovs.11-8253.

22. Chang CJ, Yang HH, Chang CA, Tsai HY. Volatile organic compounds and nonspecific conjunctivitis: A populationbased study. Aerosol Air Qual Res. 2013;13:237-42, http:// dx.doi.org/10.4209/aaqr.2012.07.0170.

23. Bourcier T, Viboud C, Cohen JC, Thomas F, Bury T, Cadiot $\mathrm{L}$, et al. Effects of air pollution and climatic conditions on the frequency of ophthalmological emergency examinations. Br J Ophthalmol. 2003;87:809-11, http://dx.doi.org/10.1136/ bjo.87.7.809.

24. Rozanova E, Heilig P, Godnic-Cvar J. The eye - A neglected organ in environmental and occupational medicine: An overview of known environmental and occupational non-traumatic effects on the eyes. Arh Hig Rada Toksikol. 2009;60:205-15, http://dx.doi.org/10.2478/10004-1254-60-2009-1869.

25. Waheed MA, Basu PK. The effect of air pollutants on the eye. I. The effect of an organic extract on the conjunctival goblet cells. Can J Ophthalmol. 1970;5:226-30.

26. Artridge RA, Stebbings JH Jr, Elsea WR, Winkelstein W Jr. Outbreak of acute eye irritation associated with air pollution. Public Health Rep. 1966;81:153-8, http://dx.doi. org/10.2307/4592670.
27. Altshuller AP. Eye irritation as an effect of photochemical air pollution. JAPCA. 1977;27:1125-6, http://dx.doi.org/10. 1080/00022470.1977.10470538.

28. Basu PK. Air pollution and the eye. Surv Ophthalmol. 1972;17:78-93.

29. Lemp MA. Report of the National Eye Institute/Industry Workshop on clinical trials in dry eyes. CLAO J. 1995;21:221-32.

30. Versura P, Profazio V, Cellini M, Torreggiani A, Caramazza R. Eye discomfort and air pollution. Ophthalmologica. 1999;213:103-9, http://dx.doi.org/10.1159/000027401.

31. Klopfer J. Effects of environmental air pollution on the eye. J Am Optom Assoc. 1989;60:773-8.

32. Andrés S, Garcia ML, Espina M, Valero J, Valls O. Tear $\mathrm{pH}$, air pollution, and contact lenses. Am J Optom Physiol Opt. 1988;65:627-31, http://dx.doi.org/10.1097/00006324198808000-00006.

33. Wolkoff P, Skov P, Franck C, Petersen LN. Eye irritation and environmental factors in the office environment-hypotheses, causes and a physiological model. Scand J Work Environ Health. 2003;29:411-30, http://dx.doi.org/10.5271/ sjweh.748.

34. Schneider T, Bohgard M. Airborne particle deposition onto the ocular surface. Indoor Air. 2005;15:215-9, http://dx.doi. org/10.1111/j.1600-0668.2005.00350.x.

35. Kiesswetter E, van Thriel C, Schäper M, Blaszkewicz M, Seeber A. Eye blinks as indicator for sensory irritation during constant and peak exposures to 2-ethylhexanol. Environ Toxicol Pharmacol. 2005;19:531-41, http://dx.doi. org/10.1016/j.etap.2004.12.056.

36. Novaes P, do Nascimento Saldiva PH, Kara-José N, Macchione M, Matsuda M, Racca L, et al. Ambient levels of air pollution induce goblet-cell hyperplasia in human conjunctival epithelium. Environ Health Perspect. 2007;115:1753-6, http://dx.doi.org/10.1289/ehp.10363.

37. Wittenborn J, Zhang X, Feagan C, Crouse W, Shrestha S, Kemper A, et al. The economic burden of vision loss and eye disorders among the United States population younger 
than 40 years. Ophthalmology. 2013;120:1728-35, http:// dx.doi.org/10.1016/j.ophtha.2013.01.068.

38. Bielory L, Meltzer EO, Nichols KK, Melton R, Thomas RK, Bartlett JD. An algorithm for the management of allergic conjunctivitis. Allergy Asthma Proc. 2013;34:408-20, http:// dx.doi.org/10.2500/aap.2013.34.3695.

39. Gupta SK, Gupta V, Joshi S, Tandon R. Subclinically dry eyes in urban Delhi: An impact of air pollution? Ophthalmologica. 2002;216:368-71, http://dx.doi.org/10.1159/000066183.

40. Azari AA, Barney NP. Conjunctivitis: A systematic review of diagnosis and treatment. JAMA Ophthalmol. 2013;310: 1721-30, http://dx.doi.org/10.1001/jama.2013.280318.

41. Bielory L. Ocular allergy overview. Immunol Allergy Clin North Am. 2008;28:1-23, http://dx.doi.org/10.1016/ j.iac.2007.12.011.

42. Pitt AD, Smith AF, Lindsell L, Voon LW, Rose PW, Bron AJ. Economic and quality-of-life impact of seasonal allergic conjunctivitis in Oxfordshire. Ophthalmic Epidemiol. 2004;11:17-33, http://dx.doi.org/10.1076/ opep.11.1.17.26437.

43. Ohnsman CM. Exclusion of students with conjunctivitis from school: Policies of state departments of health. J Pediatr Ophthalmol Strabismus. 2007;44:101-5.

44. Bielory L, Syed BA. Pharmacoeconomics of anterior ocular inflammatory disease. Curr Opin Allergy Clin Immunol. 2013;13:537-42, http://dx.doi.org/10.1097/ACI. 0b013e328364d843.

45. Bilkhu PS, Wolffsohn JS, Naroo SA, Robertson L, Kennedy R. Effectiveness of nonpharmacologic treatments for acute seasonal allergic conjunctivitis. Ophthalmology. 2014; 121:72-8, http://dx.doi.org/10.1016/j.ophtha.2013.08.007.

46. National hospital ambulatory medical care survey: 2010 emergency department summary tables [Internet]. Atlanta: Centers for Disease Control and Prevention; 2010 [cited 2014 Mar 7]. Available from: http://www.cdc.gov/nchs/ data/ahcd/nhamcs_emergency/2010_ed_web_tables.pdf.

47. Nash EA, Margo CE. Patterns of emergency department visits for disorders of the eye and ocular adnexa. Arch
Ophthalmol. 1998;116:1222-6, http://dx.doi.org/10.1001/archopht.116.9.1222.

48. Novaes P, Saldiva P, Matsuda M, Macchione M, Rangel M, Kara-Jose N. The effects of chronic exposure to traffic derived air pollution on the ocular surface. Environ Res. 2010;110:372-4, http://dx.doi.org/10.1016/j.envres.2010.03.003.

49. Saxena R, Srivastava S, Trivedi D, Anand E, Joshi S, Gupta SK. Impact of environmental pollution on the eye. Acta Ophthalmol Suppl. 2003;81:491-4, http://dx.doi.org/10.1034/ j.1600-0420.2003.00119.x.

50. Malerbi FK, Martins LC, Saldiva PH, Braga AL. Ambient levels of air pollution induce clinical worsening of blepharitis. Environ Res. 2012;112:199-203, http://x.doi.org/ 10.1016/j.envres.2011.11.010.

51. Dominici F, Zeger SL, Samet JM. Combining evidence on air pollution and daily mortality from the largest 20 US cities: A hierarchical modeling strategy. R Stat Soc Ser A. 2000; 163:263-302, http://dx.doi.org/10.1111/1467-985X.00170.

52. Canadian Institute for Health Information [Internet]. Ottawa: The Institute; c1996-2015 [updated 2015 Oct 16, cited 2014 Mar 7]. Available from: https://www.cihi.ca/en.

53. Government of Canada, Environment and Climate Change Canada [Internet]. Ottawa: The Government; c2000-15 [updated 2013 Jul 9, cited 2014 Mar 7]. National Air Pollution Surveillance Program (NAPS). Available from: http://www. ec.gc.ca/rnspa-naps/.

54. Maclure M. The case-crossover design: A method for studying transient effects on the risk of acute events. Am J Epidemiol. 1991;133(2):144-53.

55. Janes H, Sheppard L, Lumley T. Case-crossover analyses of air pollution exposure data. Referent selection strategies and their implications for bias. Epidemiology. 2005;16(6):71726, http://dx.doi.org/10.1097/01.ede.0000181315.18836.9d.

56. Bateson TF, Schwartz J. Control for seasonal variation and time trend in case-crossover studies of acute effects of environmental exposures. Epidemiology. 1999;10:539-44, http:// dx.doi.org/10.1097/00001648-199909000-00013. 
57. R Development Core Team [Internet]. Vienna: R Foundation for Statistical Computing; 2013 [cited 2014 Mar 7]. Available from: http://www.R-project.org.

58. Borenstein M, Hedges L, Higgins J, Rothstein H. Introduction to meta-analysis. West Sussex: John Wiley \& Sons; 2011.

59. Jensen-Jarolim E. Untersmayr E. Gender-medicine aspects in allergology. Allergy. 2008;63:610-5, http://dx.doi. org/10.1111/j.1398-9995.2008.01645.x.

60. Osman M. Therapeutic implications of sex differences in asthma and atopy. Arch Dis Child. 2003;88:587-90, http:// dx.doi.org/10.1136/adc.88.7.587.

61. Clough S. Gender and the hygiene hypothesis. Soc Sci Med. 2011;72:486-93, http://dx.doi.org/10.1016/j.socscimed. 2010.11.021.

62. Rosario N, Bielory L. Epidemiology of allergic conjunctivitis. Curr Opin Allergy Clin Immunol. 2011;11:471-6, http:// dx.doi.org/10.1097/ACI.0b013e32834a9676.

63. Bousquet J, Khaltaev N, Cruz AA, Denburg J, Fokkens WJ, Togias A, et al. Allergic rhinitis and its impact on asthma (ARIA) 2008. Allergy. 2008;62:8-160, http://dx.doi. org/10.1111/j.1398-9995.2007.01620.x.

64. Leonardi A, Lanier B. Urban eye allergy syndrome: An new clinical entity? Curr Med Res Opin. 2008;24:2295-302, http://dx.doi.org/10.1185/03007990802222774.

65. Bagarozzi DA, Travis J. Ragweed pollen proteolytic enzymes: Possible roles in allergies and asthma. Phytochemistry. 1998;47:593-8, http://dx.doi.org/10.1016/S0031-9422(97)00634-1.

66. Hitzfeld B, Friedrichs KH, Ring J, Behrendt H. Airborne particulate matter modulates the production of reactive oxygen species in human polymprophonuclar granulocytes.
Toxicology. 1997;120:185-95, http://dx.doi.org/10.1016/S0 300-483X(97)03664-0.

67. Sandstrom T, Forsberg B. Desert dust: An unrecognized source of dangerous air pollution? Epidemiology. 2008;19: 808-9, http://dx.doi.org/10.1097/EDE.0b013e31818809e0.

68. Coles WH, Jaros PA. Dynamics of ocular surface ph. Br J Ophthalmol. 1984;68:549-52, http://dx.doi.org/10.1136/bjo. 68.8.549.

69. Torricelli AA, Novaes P, Matsuda M, Braga A, Saldiva PH, Alves MR, et al. Correlation between signs and symptoms of ocular surface dysfunction and tear osmolarity with ambient levels of air pollution in a large metropolitan area. Cornea. 2013;32:e11-5, http://dx.doi.org/10.1097/ ICO.0b013e31825e $845 \mathrm{~d}$.

70. Liu H, Begley C, Chen M, Bradley A, Bonanno J, McNamara N. A link between tear instability and hyperosmolarity in dry eye. Invest Ophthalmol Vis Sci. 2009;50:3671-9, http:/ dx.doi.org/10.1167/iovs.08-2689.

71. Hori Y, Maeda N, Sakamoto M, Koh S, Inoue T, Tano Y. Bacteriologic profile of the conjunctiva in patients with dry eye. Am J Ophthalmol. 2008;146:729-34, http://dx.doi. org/10.1016/j.ajo.2008.06.003.

72. Szyszkowicz M, Shutt R, Kousha T, Rowe BH. Air pollution and emergency department visits for epistaxis. Clin Otolaryngol. 2014;39(6):345-51, http://dx.doi.org/10.1111/ coa.12296.

73. Dominici F, Zeger SL. A measurement error model for time-series studies of air pollution and mortality. Biostatistics. 2000;1:157-75, http://dx.doi.org/10.1093/biostatistics/1.2.157.

This work is available in Open Access model and licensed under a Creative Commons Attribution-NonCommercial 3.0 Poland License - http://creativecommons.org/ licenses/by-nc/3.0/pl/deed.en. 